\title{
The origins of marine and non-marine boulder deposits: a brief review
}

\author{
J. F. Dewey ${ }^{1}$ · J. Goff ${ }^{2,3}$ - P. D. Ryan ${ }^{4}$
}

Received: 24 June 2020 / Accepted: 25 June 2021 / Published online: 8 July 2021

(c) The Author(s) 2021

\begin{abstract}
We identify 14 mechanisms, marine and non-marine, one man made, that result and could result in the formation of boulder deposits after reviewing issues associated with clast shape, size and classification. Four of these mechanisms: storm deposits; waterspouts; cliff collapse; and catastrophic flooding below sea level, may produce deposits stretching for significant distances along shorelines which could be confused with historical or prehistoric tsunami deposits. However, recent debate has more specifically focused on parameters that can be employed in the distinction between coarse-grained tsunami and storm deposits, both of which can occur in the same location. We argue that features such as size, areal distribution and clast shape are not uniquely characteristic of either deposit. Rather, a wide variety of parameters, which reflect the period and the frequency of the transporting waves, need to be taken into account. Such analyses may be aided by profiles which evaluate the variation in modeled flow velocities with distance from the shoreline. Finally, we compare and contrast characteristics of coarse grained tsunami deposits with those of northeast Atlantic storm deposits that may aid in the identification of the transporting wave.
\end{abstract}

Keywords Boulder deposits $\cdot$ Mechanisms of formation $\cdot$ Marine $\cdot$ Non-marine $\cdot$ Review

\section{Introduction}

Shoreline boulder deposits, which often contain megaclasts (clasts with intermediate axis $>4.1 \mathrm{~m}$ ) (Terry and Goff 2014), provide a record, commonly time integrated, of extreme marine inundation events. Interrogation of this record requires that the mechanism by which these deposits are formed is correctly identified. This contribution first reviews

P. D. Ryan

paul.ryan@nuigalway.ie

University College, University of Oxford, Oxford, UK

2 Earth and Sustainability Science Research Centre (ESSRC), School of BEES, UNSW Sydney, Sydney, Australia

3 School of Ocean and Earth Science, University of Southampton, Southampton, UK

4 School of Natural Sciences, Earth and Ocean Sciences, National University of Ireland Galway, Galway, Ireland 
14 possible mechanisms that may give rise to boulder deposits, identifies those capable of producing extensive shoreline parallel deposits, and finally discusses some aspects of the current debate in separating tsunami and storm related boulder deposits. Clear distinction between these mechanisms is vital for many regions of the world where similar deposits have been the focus of considerable research such as Hawaii (Goff et al. 2006), New Zealand (Goff et al. 2018) and Australia (Courtney et al. 2012; Thomas and Schmidt 2018). We finally consider a case history comparing characteristics of storm deposits in western Ireland with those of tsunami.

\subsection{Boulder shape, size, mass and classification}

A boulder is defined as a clast having an intermediate axis $(B)$ of $0.25 \mathrm{~m}$ (Terry and Goff 2014). However, in what follows, the intermediate dimension of clasts was, commonly, not reported. The mass of a boulder of a given intermediate dimension can vary greatly: a plate or slab has $A$ (longest axis) $\geq B$ (intermediate axis) $>>C$ (shortest axis), and the volume is consequently low; whilst a rod has $A>>B \geq C$ resulting in a higher volume and mass. The relationship between minimum mass, expressed as $\log _{10}(\mathrm{~kg})$, of a boulder of rock of density $2600 \mathrm{~kg} \mathrm{~m}^{-3}$ and its "ellipticity" or "shape factor" using the Zingg diagram (Blott and Pye 2008) is shown in Fig. 1 (see "Appendix 1"). Slab-shaped boulders may have masses less than $10 \mathrm{~kg}\left(\log _{10}=1.0\right)$, whereas rod shaped boulders have a minimum mass of over $100 \mathrm{~kg}\left(\log _{10}=2.0\right)$. We have, therefore, included transport mechanisms that have deposited clasts weighing in excess of $100 \mathrm{~kg}$, which are likely to be boulders. The "shape factor" has implications for transport by rolling and sliding as both are modeled as being dependent upon C/B (Nandasena et al. 2011a, 2013; see "Appendix 2"). This ratio is larger in "elongate" forms than in "platy" forms (Fig. 1).

\subsection{The plucking and transport of boulders}

The size, sphericity, angularity, $K$ value shape (Flinn 1962), and smoothness of a boulder depends upon many factors during its origin and evolution, starting with the mechanism of detachment from bedrock, influenced by lithology, rock structure and fabric, climate and topography. Detachment mechanisms include onion-skin weathering in jointed rocks, plant roots, gravity, ice wedging and gouging, and hydraulic pressure along marine platforms and cliff bases. Transport mechanisms and the length of time between detachment and burial have a great effect on size and shape especially smoothing and rounding. Transport mechanisms may be relatively slow, such as in glaciers, mature fluvial drainage basins, longshore drift, and solifluction, or fairly rapid during "catastrophic" events, such as tsunamis and storms. Boulder transport processes such as rolling, sliding, and suspension, also vary with clast size, shape and density, and transport mechanism. This is particularly notable in rapid transport mechanisms that can vary from hyperconcentrated flows to water driven sliding, and from long to short wave periods (Goff et al 2010; Goto et al. 2010). Dewey and Ryan (2017) argue that boulders with "platy" forms are more likely to be plucked for a given storm wave population. Finally, post-burial alteration may have a profound effect on shape and strength before a new cycle of detachment to burial.

It is the purpose of this paper to review the characteristics of catastrophic boulder transport mechanisms and to distinguish between their deposits. First, we outline and review 13 natural and one man-made mechanism in the sedimentary milieu, excluding volcanogenic 


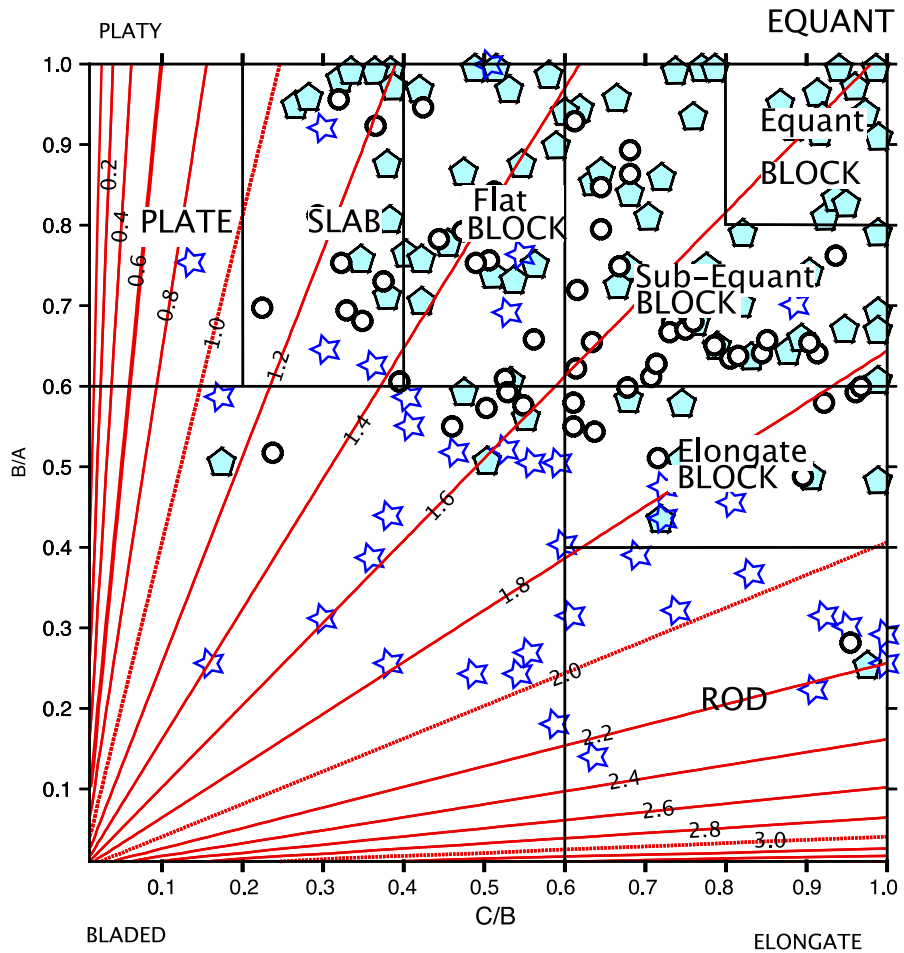

Fig. 1 Zingg Diagram after Zingg (1935) and Blott and Pye (2008) with contours (red lines) in $\log 10(\mathrm{~kg})$ of the minimum mass required for a clast of a given geometry to be classified as a boulder (see "Appendix 1"). Each order of magnitude is marked by a thicker dashed line. Boulders are plotted from: the typhoon deposit of the Gulf of Bangkok (open circles) after Terry et al. (2018; Table 2); the Miocene tsunamite from Waitemata, New Zealand (pentagons) after Dewey and Ryan (2017; Supplemental Data Table S2); and the storm deposits from Annagh Head, western Ireland (open stars) after Dewey and Ryan (2017; Supplemental Data Table S3). Note that the boulders from the Waitemata tsunamite and the Gulf of Bangkok typhoon generated deposit have similar shape distributions

and bolide impact-related deposits. We note here that most of the non-marine mechanisms could lead to flows into the sea to give localized boulder deposits.

\section{Mechanisms of boulder deposit formation}

\subsection{Tsunamis-seiches}

Tsunami and seiches are primarily generated by subduction-interface earthquakes, gravityslide masses, volcanic explosion-flank collapse-lateral blasts, and bolides. Run-up, wave height, and carrying capacity (e.g., Nott 2003; Barbano et al. 2010) depend on sea-bed displacement volume and energy generated at origin, the bathymetric geometry of the shallowing seabed, subaerial landform in the run-up region, and whether or not the run-up is laterally confined or concentrated as in a narrow or funnel-shaped bay, such as the Bay of Fundy and Bristol Channel or submarine canyons. Only tsunamis, contrasted to other 
waves, can affect hundreds to thousands of miles of the coastlines in the oceans and seas in which they originate.

Tsunamis can be associated with numerous related hazards. For example, small earthquakes can cause massive slide displacements that generate tsunamis, and there may be a strong hazard relationship between earthquakes, tsunamis and volcanic collapse as in the US Pacific Northwest, where Seattle may be at simultaneous risk from a large subduction earthquake, resultant tsunami, and the collapse of the hydrolyzed and fragile Mt. Rainier with west-flowing mega-lahars. A mega-tsunami was generated by the 65 Ma Chicxulub impact when $120 \mathrm{~m}$ high waves, decaying to $10 \mathrm{~m}$ over $5000 \mathrm{~km}$ from the Yucatan Peninsula, transported impact-generated and shell sands at least that distance with the deposit possibly including $8 \mathrm{~m}$ meso-boulders laid down in Arkansas some $800 \mathrm{~km}$ inland (Smit et al. 1996). It has been claimed that a large, midfifteenth century tsunami swept the eastern margin of Australia with jagged bed-rock stripping, fluting, and transporting of boxcar-size megaclastic rocks overtopping $130 \mathrm{~m}$ cliffs (Bryant and Nott 2001; Bryant and Young 1996), a possible origin being a bolide striking to form the Mahuika Crater south of New Zealand, an event with a possible link to the destruction of part of the Chinese Zheng He Fleet. This hypothesis has been questioned by Goff et al. (2010) and Courtney et al. (2012). We go further and consider these Antipodean arguments to be in the realm of fantasy (Goff et al. 2003); our examination of the common slab imbrication and other features at Jervis Bay in eastern Australia suggests a multiple storm, not a tsunami, origin for the fields of flipped boulders (e.g., Thomas and Schmidt 2018).

Tsunamis are also associated with volcanic flank collapse, volcanic landslides, lateral surges, and explosions, including the Canary Islands, Santorini, Krakatoa, and Hawaii. Flank collapse of Pico de Fogo, 75,000 bp, in the Cape Verde Islands probably caused a mega-tsunami that yielded a $270 \mathrm{~m}$ run-up, which transported boulders up to 400 tonnes (Ramalho et al. 2015). Pyroclastic flows and derivative volcaniclastic turbidites resulting from powerful, fast, superheated lateral surges, staying on land from Mt. St. Helens but flowing into the sea from Soufriere (Mattioli et al. 2007) add momentum to generate tsunamis and carry volcanic boulders for tens of $\mathrm{km}$. The Hawaiian $120 \mathrm{Ka}$ mega-tsunami was most likely generated by a flank collapse of Mauna Loa with run-ups of over $400 \mathrm{~m}$ when sea level was $290 \mathrm{~m}$ lower than present, with chaotic deposits of lava boulders, soil, and coral fragments cemented by coralline sand (McMurtry et al. 2004; Noormets et al. 2004). In the Ryukyu Islands, Japan, tsunami run-up deposited at least one $2500 \mathrm{t}$ "tsunami-ishi" meso-boulder $50 \mathrm{~m}$ inland on top of $12.5 \mathrm{~m}$ high cliff with smaller ones farther inland at higher elevations (Goto et al. 2010). In western Crete, boulder fields have 75 t blocks (Scheffers and Kelletat 2003); the 1,500 BC eruption of Santorini (Thera) may have been the cause although there is evidence for strong tsunami action from 1530 to 1821 AD (Boulton and Whitworth 2018). In Tonga, subrounded meso-boulders of coral-reef carbonate (dated from 120 to $130 \mathrm{Ka}$ ), the largest $15 * 11 * 9 \mathrm{~m}$ and 1600 tonnes, were transported, probably rolled, by 19-44 $\mathrm{m}$ waves up to $400 \mathrm{~m}$ from the shoreline. These were most likely emplaced by a tsunami generated by local volcanic flank collapse and/or submarine land sliding around $7 \mathrm{Ka}$ (Frohlich et al. 2009). During the 1883 eruption of Krakatoa, a $36 \mathrm{~m}$ tsunami displaced a $317 \mathrm{~m}^{3}$ meso-boulder of coral limestone $100 \mathrm{~m}$ inland (Simkin and Fisk 1983). In 1958, at the eastern end of Lituya Bay, a narrow-mouthed inlet of the Gulf of Alaska, a $31 \times 10^{6} \mathrm{~m}^{3}$ rock mass fell $800 \mathrm{~m}$ into the Bay generating a massive seiche (Miller 1960; Fritz et al. 2009) with a vegetation-stripping trim-line run-up of $524 \mathrm{~m}$ and a gravity wave traveling out of the Bay at up to $130 \mathrm{mph}(209 \mathrm{kph})$. 
Tsunamis/seiches also occur in lakes, e.g., Lake Tahoe in the East California transtensional zone where the Holocene $10 \mathrm{~km}^{3}$ McKinny Bay slide mass, probably generated by a $4 \mathrm{~m}$ slip on the West Tahoe Fault, caused a powerful lacustrine tsunami with $8 \mathrm{~m}$ run ups re-depositing glacial boulders in $2 \mathrm{~m}$ ridges and transporting others of up to about $1 \mathrm{~m}$ as far as $15 \mathrm{~km}$ from the western shelf (Ichinose et al. 2000; Moore et al. 2006).

\subsection{Storm, hurricane, tropical storm, cyclone-typhoon, rogue, freak waves}

Wave height is determined by wind speed, fetch and duration. Storm waves typically occur as a wave field or train with an average height of $3.5 \mathrm{~m}$, a general maximum height of $6 \mathrm{~m}$, and a 60-80 m wavelength with a $10 \mathrm{~s}$ period. More powerful, long-fetch (reach) waves, such as graybeards and Cape Horn Rollers may be up to $60 \mathrm{~m}$ high. Hurricane-induced waves commonly have heights of $18 \mathrm{~m}$ but those of Hurricane Ivan were up to $30 \mathrm{~m}$ high in wave fields of $18 \mathrm{~m}$ waves (Wang et al. 2005). The 1899 tropical super-cyclone Mahina in northern Australia generated a $13 \mathrm{~m}$ storm surge that carried macerated debris up to $5 \mathrm{~km}$ inland (Nott et al. 2014). Rogue, freak, or extreme storm waves, greater than twice average wave height and generated by cumulative wave interference and addition, such as the 1995 Draupner wave in the North Sea, may achieve heights of $30 \mathrm{~m}$ with a momentum breakingforce of $100 \mathrm{t} / \mathrm{m}^{2}$ (140 psi) (Adcock et al 2011), sufficient to destroy large ships and move $100 \mathrm{t}$ boulders. In 1861, a $>67 \mathrm{~m}$ wave overtopped a $60 \mathrm{~m}$ cliff and $7 \mathrm{~m}$ lighthouse on Eagle Island north of Annagh Head in Co. Mayo, western Ireland (Fig. 2), and, in 1985, a $47 \mathrm{~m}$ wave struck the Fastnet lighthouse, $6.5 \mathrm{~km}$ off Mizen Head in southwest County Cork in southwest Ireland (O'Brien et al. 2013). In January 1607, a massive wave surged up the Bristol Channel narrowing and rising to $18 \mathrm{~m}$ and flooding over $500 \mathrm{~km} 2$ along $300 \mathrm{~km}$ of coastline; it transported $50 \mathrm{t}$ boulders and killed more than 2000 people.

Numerous storm deposits have been identified in the northeast Atlantic region (e.g., Williams and Hall 2004; Hall et al. 2006; Cox et al. 2012; 2018; Dewey and Ryan 2017; Suanez et al. 2009). These occur in several forms: cliff top boulder deposits where overhanging slabs near the tops of cliff have been flipped and washed back to form a boulder ridge or berm (Barbano et al. 2010); boulder ridges formed from plucked boulders which are often imbricated on wave-cut rock cut platforms; and isolated boulders on such platforms. Maximum clast sizes exceed 500 tonnes in the Aran Islands (Cox et al. 2018; Cox 2020) and direct observation shows that meso-boulders have been moved by recent storms. Such deposits, although restricted to exposed locations, extend over $100 \mathrm{kms}$ along the oceanic shoreline in a region exposed to severe winter storms (Fig. 2c, d).

\subsection{Mudslides and flows}

Mudslides and mudflows such as those in the White Mountains, California, where heavy intermittent thunderstorms create flash floods and sediment slurries containing boulders weighing up to 8,000 tonnes flowing from canyon mouths and down alluvial fans. The subsequent wind and water winnowing of the finer grained-matrix leads to boulder ridges forming on the fan surfaces. Boulder sizes here are related to rock type; meso-boulders are mostly granitoids because of the wide joint spacing whereas the smaller boulders are derived from the intensely jointed sedimentary and metamorphic rocks (Beaty 1989). Another more common mode of mudslide is caused by heavy rainfall onto steep slopes. There are numerous examples but in recent times these include the 2014 Oso mudslide 


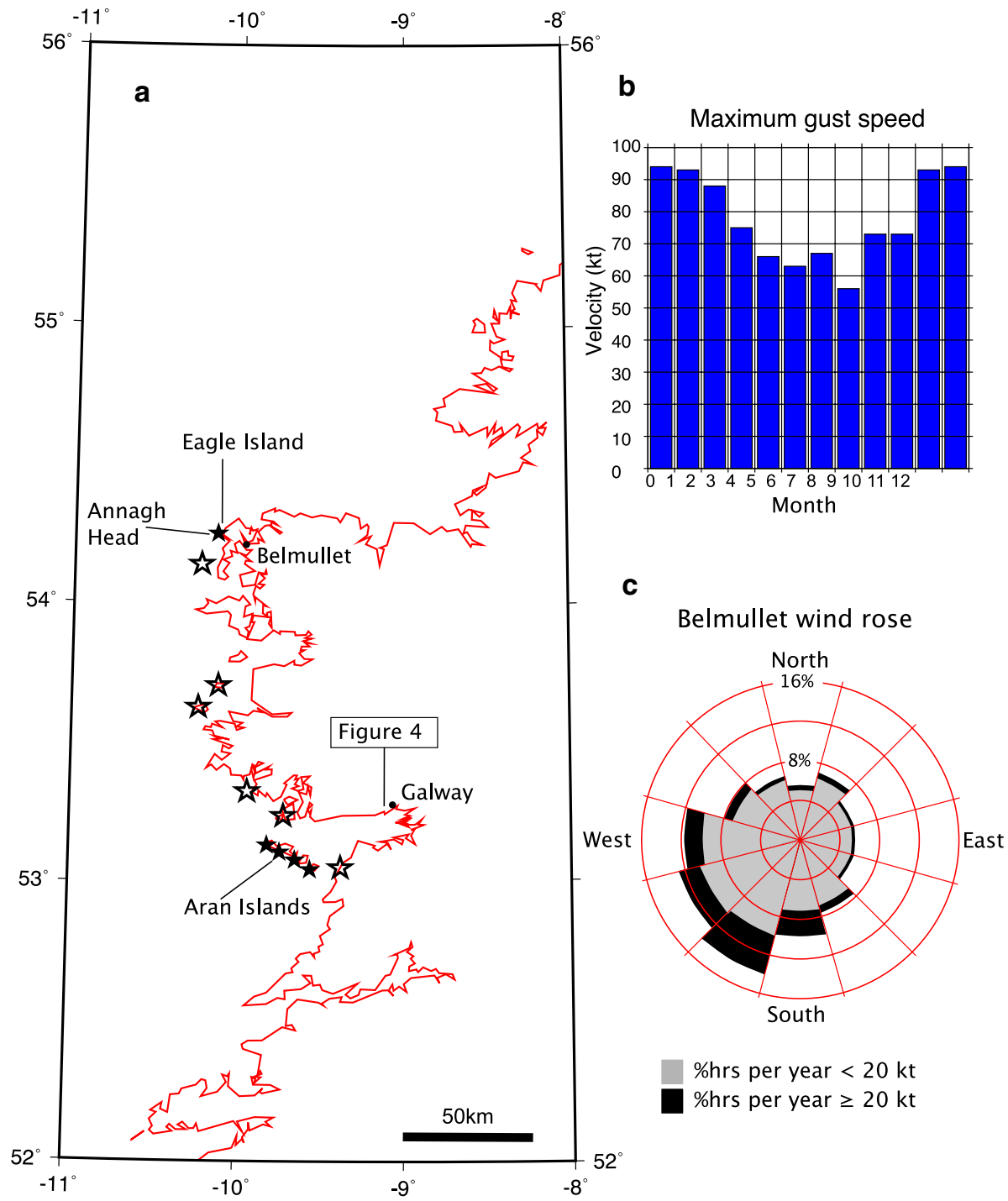

Fig. 2 a Map of the western coast of Ireland showing the locations of cliff top storm boulder deposits. Lines of latitude and longitude are shown, as is the location of Fig. 4. Closed stars mark locations where it has been argued these deposits are of storm origin (Aran Islands: Williams and Hall 2004, Cox et al. 2012, 2018 and Annagh Head: Dewey and Ryan 2017). Open stars mark locations identified from satellite photographs where ridges containing boulders greater than $2 \mathrm{~m}$ in intermediate dimension form on rocky foreshores at least $30 \mathrm{~m}$ from the median shoreline. b Maximum recorded gusts at the Belmullet weather station. Source: Éireann (2019) by month for the period 1981-2010. The highest wind speeds recorded were $172 \mathrm{kph}(\sim 93 \mathrm{kt})$ on 9th February 1988 at Belmullet and $182 \mathrm{kph}(\sim 98 \mathrm{kt})$ at Foynes Airport 18th January 1945. c The Belmullet wind rose 1954-2014. Source Éireann (2019)

where a glacial till overlying porous sand and mudstone led to the liquefaction of the mudstone and a consequent $60 \mathrm{kph}$ mudflow containing rafted sandstone blocks that covered $2.6 \mathrm{~km}^{2}$ (Stark et al. 2017). An equally complex mudslide was the compound landslide 
disaster of April 1st, 2017 in Mocoa, southern Colombia, that was in the form of an "avalanche" of a dilute fast-moving, flood-water-generated mudflow (locally known as Huacos) that transported boulders up to $50 \mathrm{t}$ (Cheng et al. 2018). The occurrence of mudslides in alternating beds of soft sandstone, mudstone or shale is quite common and in tectonically active areas this can lead to repeated failures caused not only by heavy rains but also seismic activity. The Tsaoling landslide, one of the largest landslide areas in Taiwan, has been affected by six catastrophic failures since 1862 with the last caused by the 1999 Chi-Chi earthquake (Chigira et al. 2003). The earthquake triggered some 9727 landslides in total (Liao 2000) of which the Tsaoling landslide displaced some $125 \times 10^{6} \mathrm{~m}^{3}$ of rock including meso-boulders as large as $10 \mathrm{~m}$ in diameter (Chigira et al. 2003; Hung 2000).

\subsection{Flash floods in steep river valleys}

Following heavy rains of tropical intensity over a large catchment feeding into narrow, steep river valleys, 50 t boulders may be carried, and disgorged onto steep rocky coast deltas (see, for example, Archer and Fowler 2018). This occurred at Glenridding in Cumbria in 2015, on the north Cornish coast at Boscastle in 2004, and north Devon coast at Lynmouth in 1952 where dams of fallen logs broke to send catastrophic walls of water down the Lyn Valley. Breaching of natural dams created by landslides caused flash floods in the Alaknanda and Bhagirathi valleys, Uttarakhand Himalaya, in 1894 and 1970, the latter leading to the loss of around 4000 lives (Rana et al. 2013). In the USA, large flash flood deposits in the Colorado Front Range can contain boulders with intermediate dimensions up to $3.29 \mathrm{~m}$ (Costa 1983). A combination of an earthquake in 1941 and heavy rain in 1942 formed a boulder-rich dam in the Ching-Shui river, Taiwan, 140-200 m high and $4800 \mathrm{~m}$ at its base. The dam breach catastrophically in 1951 transporting a boulder-strewn slurry downstream and resulting in 137 deaths (Hung et al. 2002).

\subsection{Waterspouts}

In New Zealand waterspouts have moved boulders measuring over $2 \mathrm{~m}$ long at least $60 \mathrm{~m}$ above sea level in prehistory, mimicking similar historical events that have seen similar sized boulders carried over $45 \mathrm{~m}$ above sea level (Fig. 3). While these tend to be deposited in a broad swath across hillsides, multiple events over time can produce high elevation boulder fields (Goff et al. 2016).

\subsection{Catastrophic flooding of areas below sea level}

There are forty two extant areas below interconnected global sea level on the continents formed by a variety of causes including stretching (Dead Sea, Death Valley), flexural loading by thrusts (Turfan Depression), and wind ablation (small Saharan depressions). Rapid sea-level rise and the destruction of barriers suggest the possibility of "in-burst" floods. Evaporation of constricted seas and oceans such as the Mediterranean during the late Miocene (Garcia-Castellanos et al. 2009), and the South Atlantic during the early Cretaceous (Burke and Sengör 1988) led to catastrophic flooding of these ocean basins and the transport of clastic detritus including boulder beds emanating from canyon mouths generated during the evaporative drawdown. 

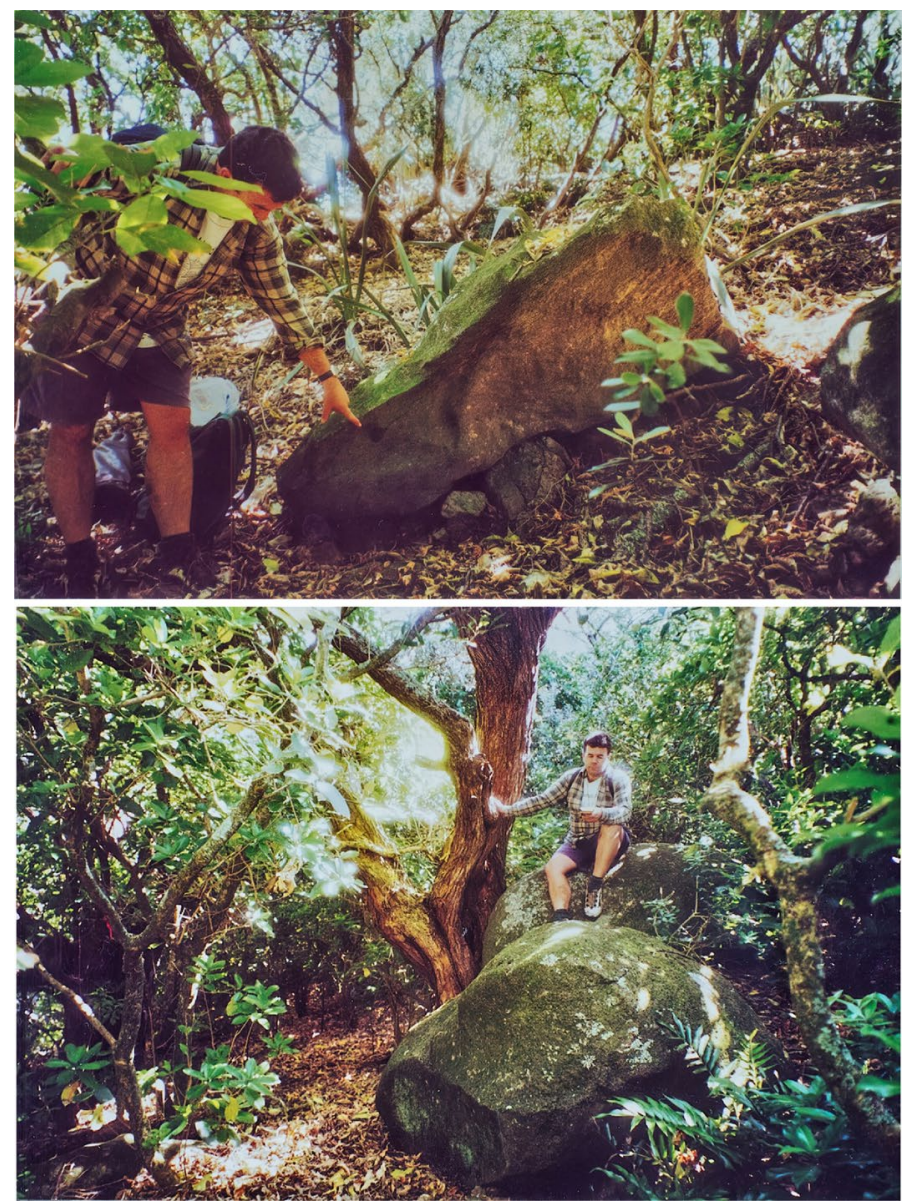

Fig. 3 a, b Korapuke Island, New Zealand. Boulders from a deposit 60-80 m above sea level. Boulders were sourced from the shore platform, with evidence of a wave cut notch visible on the right hand side of the boulder and gastropod borehole indicated in a After Goff et al. (2016)

\subsection{Gravity collapse of cliffs by toppling}

Gravity collapse of cliffs by toppling (Violante 2009) or numerous forms of land sliding (Iadanza et al. 2009) is a common phenomenon on rocky shorelines and can cause boulder deposition or re-deposition. However, it can be problematic distinguishing such boulders from those formed by tsunami or storm plucking. When such boulders are new and fresh, they are angular but become progressively rounded with age if they remain at the base of the cliff. In high-latitude regions subjected to recent glaciation, the wave erosion of cliffed boulder clay deposits can lead to boulder fields, even in regions of low wave energy (McGreal 1979; Dawson and Stewart 2008). For example, boulder fields containing clasts of $B>2.0 \mathrm{~m}$ can be found in "ghost"-eroded drumlins along the north shore of Galway Bay, some $55 \mathrm{~km}$ from the open ocean (Fig. 4). 


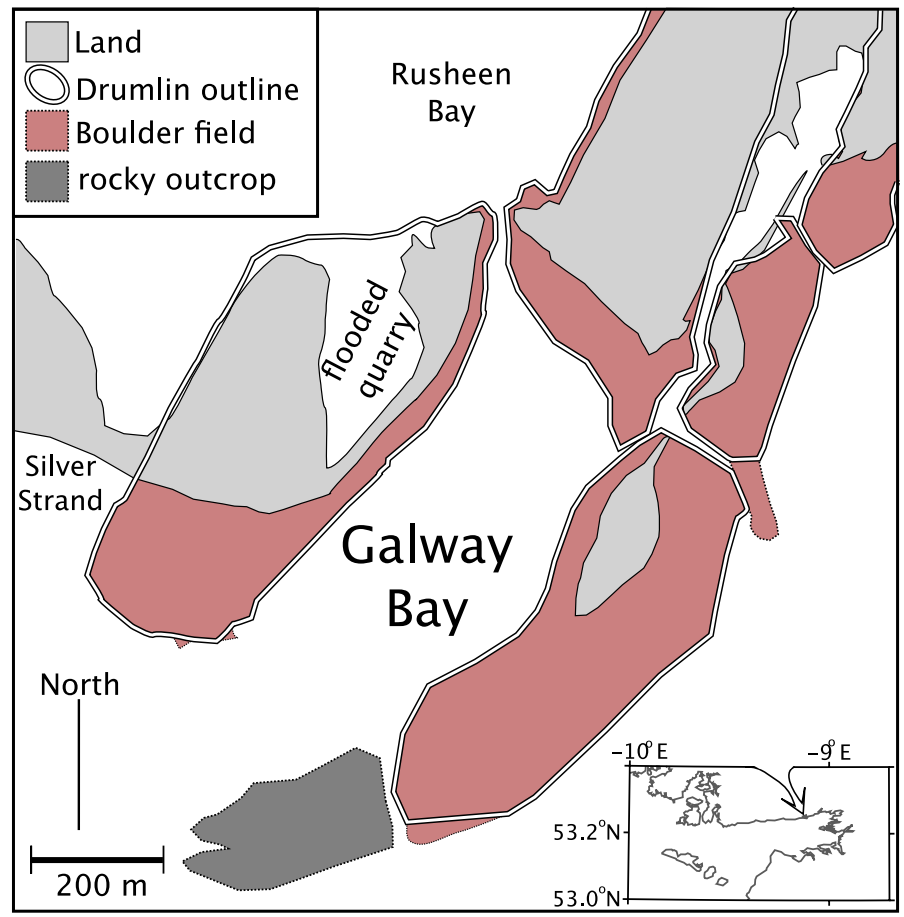

Fig. 4 Line drawing of boulder fields "ghosting" eroded drumlins in the Silver Strand area of Galway City based upon satellite images

\subsection{Tidal Bores}

Long gradually constricting river mouths, estuaries, and funnel-shaped bays, such as the Bay of Fundy and the Severn/upper Bristol Channel, commonly channel fast tidal bores with run-ups as high as $15 \mathrm{~m}$, which are capable, episodically, of moving small boulders. This phenomenon occurs in over 400 estuaries globally (Chanson 2012). Estuaries with hypertidal bores generally contain mud to gravel (Archer 2013) but flow velocities of up to $5.5 \mathrm{~m} / \mathrm{s}$ may rework boulders introduced by ice-rafting or other mechanisms.

\subsection{Channeled swells}

West of Praio do Norte, Nazaré, western Portugal, a deep-water canyon, running to the shore, channels and enhances Atlantic swells to $27 \mathrm{~m}$ waves (Cunha and Gouveia 2015). The canyon was subject to higher energy processes in pre-Holocene times which led to the transport of boulders in excess of "1 m across" (Tyler et al. 2009).

\subsection{Ice-related transport}

Ice-related transport includes avalanching of hanging glaciers, ice rafting, glacial outbursts (Jökulhaups), and the development of glacial strain-induced boulder ridges (Darwin's 
boulders; Evenson et al. 2009). Major prehistoric glacial outbursts such as the catastrophic draining of Glacial Lake Missoula (GLM), in western Montana, USA, can cause widespread flooding, instantaneous erosion and the deposition of huge volumes of sediment. In the case of GLM, this includes the deposition of boulder-sized clasts and larger in western Washington some $700 \mathrm{~km}$ to the west (Bretz 1925). The mechanisms of transport and deposition for ice rafted boulders may be masked by subsequent reworking. Whilst characterized by erratic lithologies, identification of original mechanisms may require careful analysis (for example, Evenson et al. 2009).

\subsection{Dry boulder avalanches}

Dry boulder avalanches are commonly funneled down steep gorges, where bouncing boulders derive kinetic energy from mutual collisions with consequent low-friction boulder slides but with sufficiently energetic collision to cause local flash melting (De Blasio et al. 2008) and boulder splitting. Debris volumes are typically up to $10^{6} \mathrm{~m}^{3}$ with anomalously long runouts, such as the 1881 Elm, Switzerland (Conway 1900, pp. 178-184) and 1903 Frank, Canada (McConnell and Brock 1904) boulder slides. These sturz-strom phenomena have been termed dry acoustic fluidization avalanches (Melosh 1987).

\subsection{Sailing stones}

At Racetrack Playa, Death Valley National Park, USA, there has been considerable debate through the years concerning the apparent "sailing" of numerous angular boulders up to $320 \mathrm{~kg}$ that have tumbled onto the playa surface. These rocks leave rock-carved trails along the occasionally flooded lake bed some $1130 \mathrm{~m}$ above sea-level. Recent research (Lorenz et al. 2011) indicates that when this apparent "sailing" occurs when the moderately weak winds blow on the rocks and floats them off the soft bed on small rafts of ice. Transport distances of up to $150 \mathrm{~m}$ have been measured for this process that has also been noted to occur on arctic tidal beaches where the boulders terminate inland to form boulder barricades (Lorenz et al. 2011).

\subsection{Mega rock flows}

The mega rock flows of the dry western margin of the Andes may be, in an area with little or no fluvial drainage, the principal catastrophic mechanism for transporting sediment including meso-boulders from the Andes to the Peru Chile Trench. In 1970, a flow was generated by the collapse of a rock cliff onto the head of a glacier, generating a lethal combination of shaved ice, comminuted rock and compressed air, which flowed down the glacier to emerge onto the seaward sloping plain and to travel at speeds of 280-335 kph distributing clastic detritus and angular boulders weighing several tonnes (Plafker et al. 1971).

\subsection{Man-made dam collapse}

In 1928, the St. Francis Dam, a curved concrete structure in the southwest Sierra Nevada, California, failed resulting in the instantaneous release of $1.4 \times 10^{9}$ gallons of water in a $34 \mathrm{~m}$ wall that flowed down the Santa Clarita Valley to discharge into the Pacific at Ventura $80 \mathrm{~km}$ from the Dam (Waltham 2018). Masses of sediment, boulders and segments of the 
dam, cars, destroyed buildings, and 450 bodies were swept to the coast. One $9000 \mathrm{t}$ block was transported for over a kilometer. Dam collapse and the catastrophic draining of Lake Berryessa and Lake Oroville in northern California (White et al. 2019) have catastrophic potential, whereas the 1963 Vajont Dam collapse in Italy (Kilburn and Petley 2003) and perhaps two of the most famous dam collapses of World War 2-The Mohne and Ederdestroyed by the allied "bouncing bomb," are similar examples of boulder transport.

\section{Mechanisms capable of producing shore parallel boulder deposits}

Tsunamis, storms (including extreme marine inundation events), waterspouts, cliff retreat and catastrophic flooding below sea level all have the capability of producing extensive, commonly shore-parallel boulder deposits (Table 1), which may contain meso-boulders. These produce significant "replication" (Goff et al. 2012,2016) of continuous or discontinuous deposits along tens, if not hundreds, of kilometers of shoreline. There has been considerable discussion about how tsunami and storm generated deposits, which can cover entire coastlines, can be distinguished (e.g., Nott 2003; Atwater et al. 2012; Richmond et al. 2011; Goff et al. 2012; Spiske et al. 2020, and references therein). The limited amount of research on waterspout deposits means that the potential nature and extent of these sediments is still poorly understood (Goff et al. 2016). Cliff retreat is related to a specific geomorphology and should, therefore, be easily identifiable. Catastrophic flooding is of short duration, measured in months or years (GarciaCastellanos et al. 2009), and the resultant deposits are rapidly inundated by the rising sea. The two most common transport mechanisms which should be investigated are therefore tsunamis and storm waves.

\section{Tsunami versus storm deposits}

Initial debate often focused on the mass of the largest boulders or other megaclastic rocks. However, recent studies and model simulations (e.g., Dewey and Ryan 2017; Goff et al. 2018; Watanabe et al. 2019; Cox et al. 2020) suggest that this alone is not a sufficient criterion. It is also impossible, now, to distinguish such deposits based on cumulative histograms of size (Dewey and Ryan 2017) or shape factor which is probably controlled more by bedrock jointing or reef morphology than transport mechanism. We discuss below several criteria that may be useful in distinguishing such deposits.

\subsection{Inland distribution}

One of the more compelling examples of a study comparing storm and tsunami deposited boulders and meso-boulders is from Japan (Goto et al. 2010). On the Ryukyu Islands, an archipelago affected by typhoons and tsunamis over recent centuries, there are numerous megaclastic rocks deposited on the fringing reef and on land. In a study of 626 boulders and meso-boulders two distinct groups were found-on the reef crest and along the shoreline. On the reef, storm boulders up to $47 \mathrm{t}$ originating from the reef slope and reef crest were deposited 50-240 $\mathrm{m}$ from the reef edge and fined inland. Landward of a $100+\mathrm{m}$ gap in deposited boulders was the second group comprising 
(1)

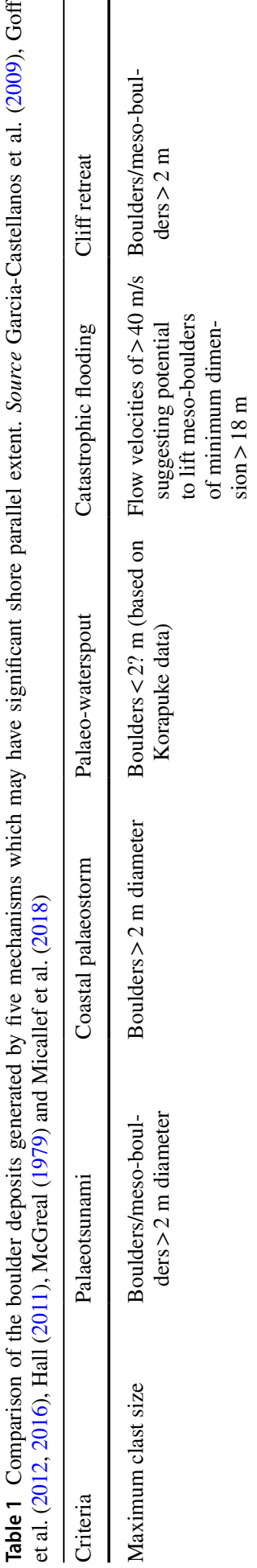

$\frac{5}{5}$
0
0
8
0
8

立 $\frac{1}{8}$

흘

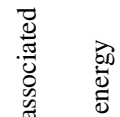

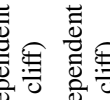

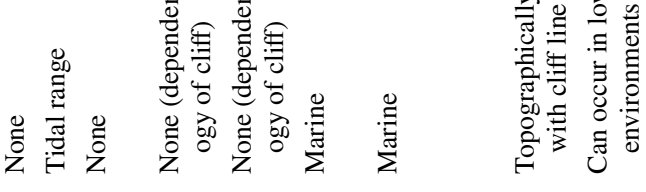

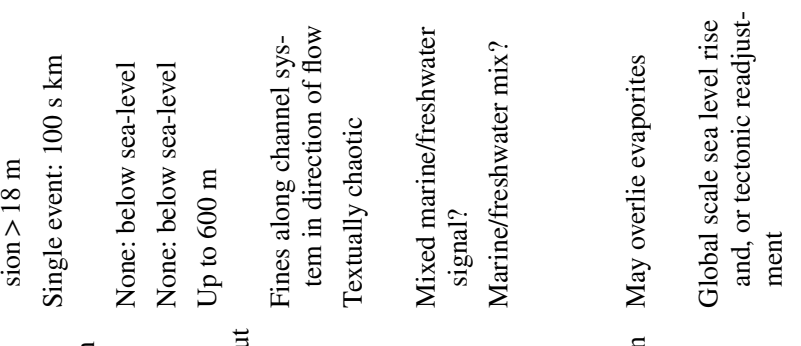

$\Xi \underline{\Xi}$

产

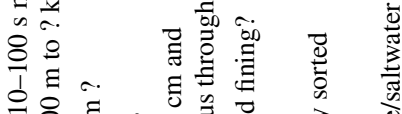

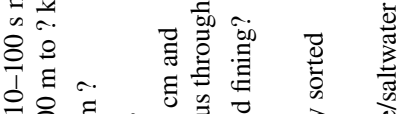

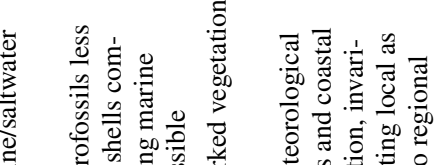

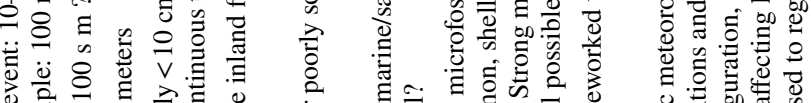

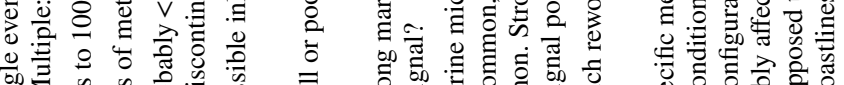

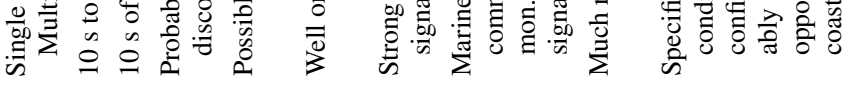

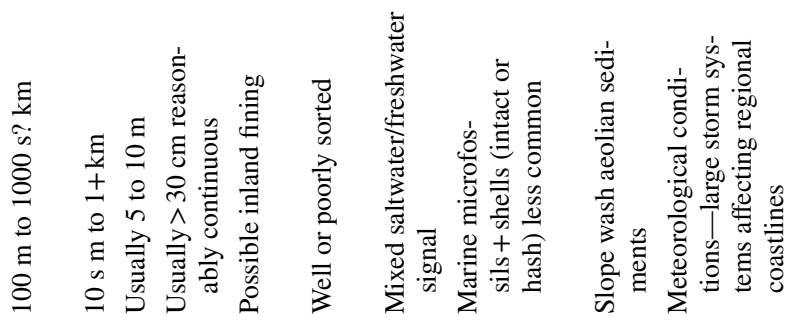

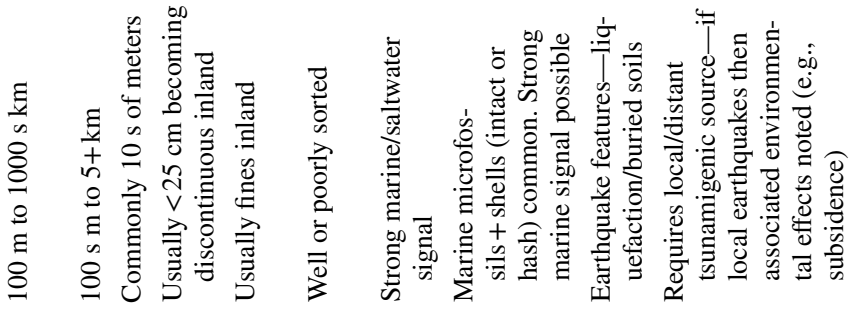

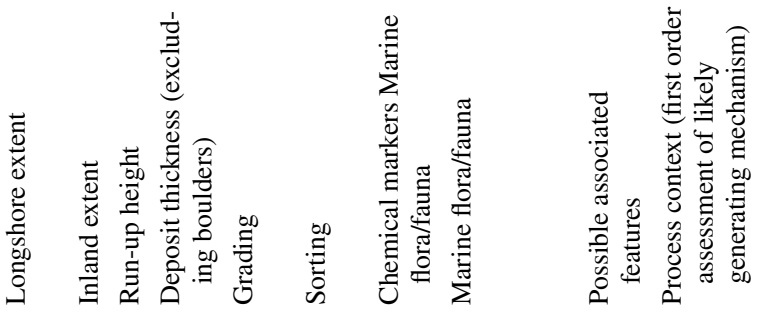


abundant coral boulders and meso-boulders weighing up to $216 \mathrm{t}$ scattered randomly along the shoreline, 390-1290 $\mathrm{m}$ from the reef edge. These were far beyond the transport limit of boulders by storm waves. They originated from the 1771 Meiwa Tsunami. Such sites offer us a glimpse at possible solutions to differentiating between storm and tsunami-lain megaclastic rocks.

\subsection{Inland fining}

Another approach is to study the variation in flow velocity along the profile. It would be expected that tsunamis with flow velocities capable of moving boulders or larger clasts would not show a noticeable decrease in velocity over a short $(10 \mathrm{~s}-100 \mathrm{~s} \mathrm{~m})$ profile along a flat shoreline. However, this is not always the case with little to no discernible fining inland reported in some instances such as at Lhok Nga, Indonesia, following the 2004 Indian Ocean tsunami where clast-to-clast interactions at the inception of transport greatly affected transport distance (Nandasena et al. 2011b). A similar effect was most likely also responsible for the palaeotsunami boulder field found at Okawa Point, Chatham Is, New Zealand (Goff et al. 2018). Storm deposits should, because of the decrease in flow velocity of a breaking wave (Sunamura 1985; Noormets et al. 2004), show a noticeable decrease along similar sections. Figure 5 shows the variation in minimum flow velocities with distance from the shoreline, derived using the equations of Nandasena et al. (2011a, 2013; "Appendix 2"), required to initiate boulder transport by lifting, rolling or sliding for two boulder deposits. The first at Annagh Head, County Mayo, Ireland interpreted as the result of storm action (Dewey and Ryan 2017) and the second, along the east shore of Sicily, a consequence of both tsunami and storm action (Barbano et al. 2010). The Annagh Head deposit shows a decrease in minimum required velocities for all three modes of transport with distance (Fig. 5a), whereas that of Sicily shows a remarkable consistency, particularly for the minimum flow velocity to initiate lifting (Fig. 5b). Also, the two rose diagrams showing the trend of the longest boulder axis (Fig. 5c, d) show a stronger alignment in the Annagh Head storm deposits, which would be expected if the beach was modified by multiple storms on the same vector (Fig. 2c, d). Care must be exercised in making this comparison because sampling methods were not standardized, for example the Irish data are from a longer controlled profile at one location (see Dewey and Ryan 2017 for details), whereas that of Sicily was across three locations.

\subsection{Location and extent of sites along shoreline}

Watanabe et al. (2019) argue that as storm waves have periods of $10 \mathrm{~s}$ of seconds their hydraulic force is rapidly attenuated inland. Accumulations of storm transported boulders in a cliff-top setting require that the site is subject to either many storm waves in one event or frequent repeated storms. The longer period tsunamis are subject to less dissipation of hydraulic force inland, leading to the distribution of boulders at a wide variety of locations irrespective of their size (e.g., Goto et al. 2010). Dewey and Ryan (2017) show the cliff-top storm deposit at Annagh Head, North Mayo, is localized having an aerial distribution of $120 \mathrm{~m} \times 180 \mathrm{~m}$ in spite of being in a region of frequent storms (Fig. 2b, c). They contrast this with the Lower Miocene tsunamite of the Matheson Formation, New Zealand, which covers some $80,000 \mathrm{~m} \times 5800 \mathrm{~m}$. 

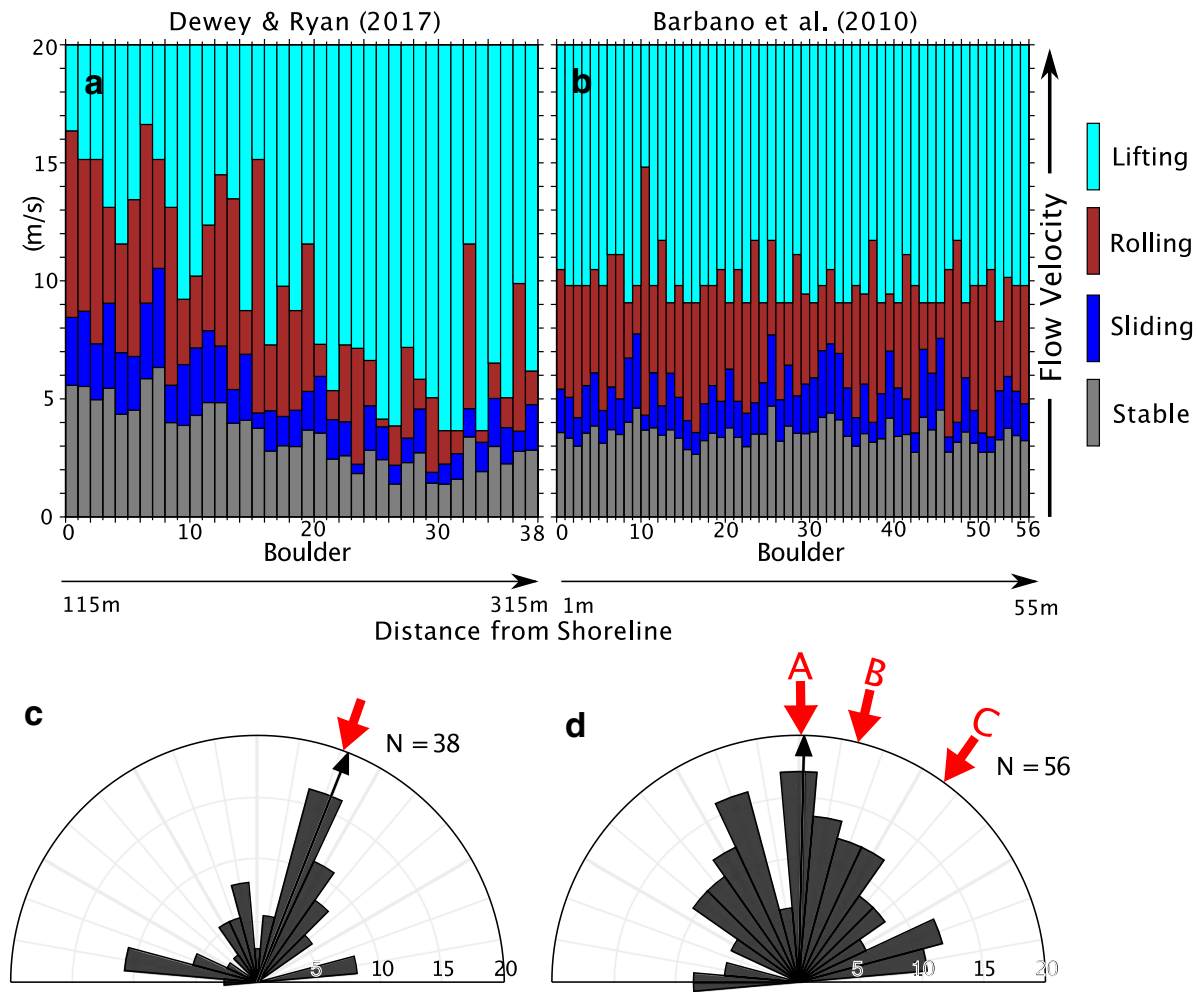

Fig. 5 Plots showing the minimum flow velocity required to initiate transport by lifting (light blue), rolling (red) and sliding (dark blue) of boulders from a Annagh Head and b Sicily. The base of each column marks the minimum velocity required to initiate that mode of transport. The plots are arranged in increasing distance from the shoreline from left to right, the actual range of distances is plotted on the abscissa. Rose diagrams $\left(180^{\circ}\right)$ showing the orientation of the long axis of each boulder are plotted for $\mathbf{c}$ Annagh Head and d Sicily. Data for Annagh Head was from Dewey and Ryan (2017; Table S3) and for Sicily from Barbano et al. (2010; Table S3). The requisite flow velocities required for each mode of transport was calculated using the equations Nandasena et al. (2011a, 2013; Appendix 2). The method is fully described in Terry et al. (2018)

\subsection{Geology of deposit}

Table 2, based on Goff et al. (2012; Table 1) and Dewey and Ryan (2017; Table 2) compares the principal characteristics of coarse grained tsunami deposits with those of a large storm such as those from northeast Atlantic storms, and other mechanisms. The combined wave energy associated with storms and many tsunamis can be similar (Montoya and Lynett 2018) so that distinguishing between these two types of deposit depends more on those aspects of their internal structure that reflect the wave period (Table 2). The principal geological features that distinguish such deposits are that tsunami deposits have generally poorer sorting, structures that reflect several inundations and imbrication caused by both run-up and backwash. NE Atlantic storm deposits rest on a wave-cut rocky platform, show imbrication associated with run-up and fine rapidly inland, if at all. Both deposits can have lateral extents of over $100 \mathrm{~km}$. Storm deposits have been recorded on cliff tops at heights of up to around $30 \mathrm{~m}$ (Williams and Hall 2004) and inland for $400 \mathrm{~m}$ (Dewey and Ryan 2017). 


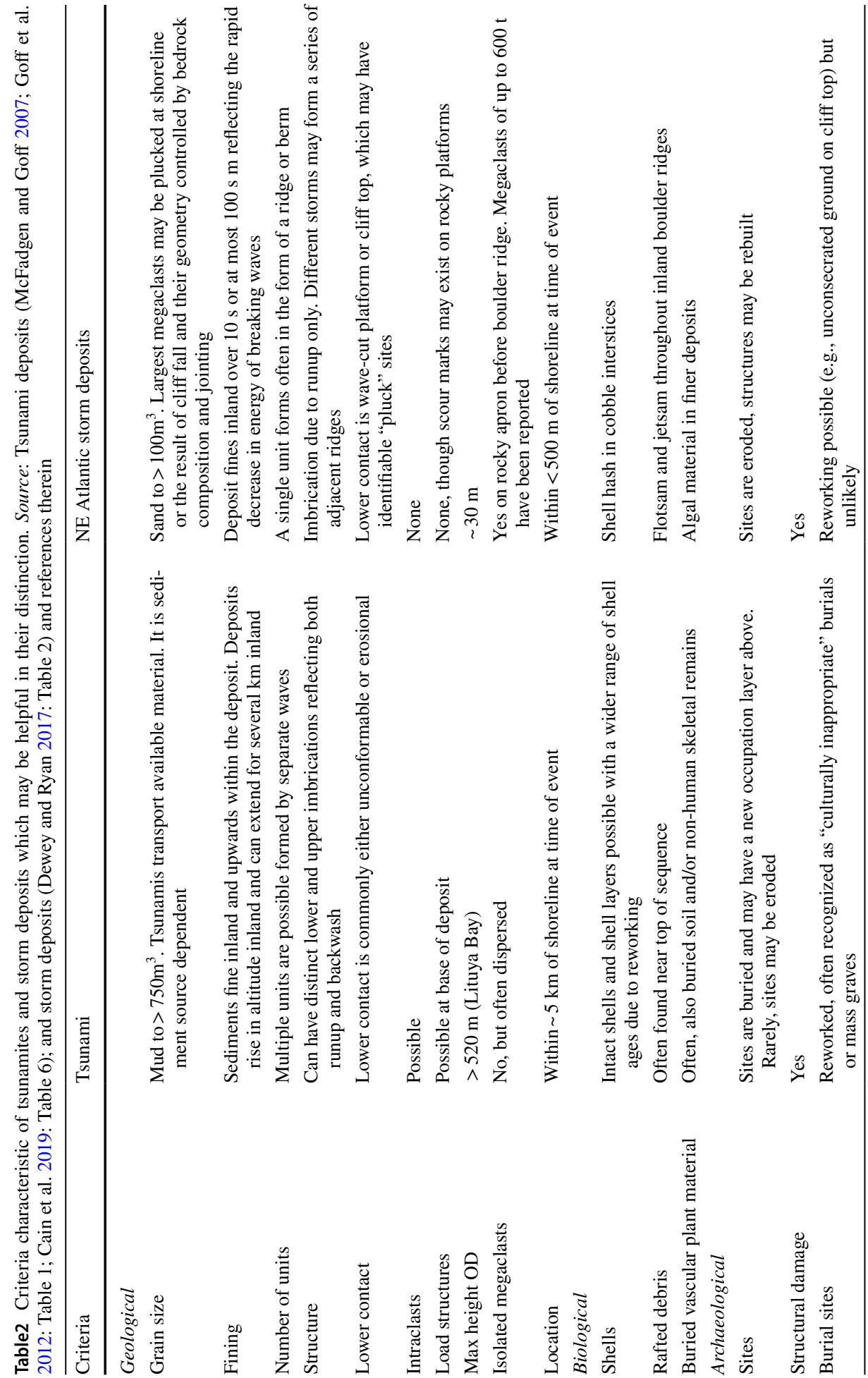




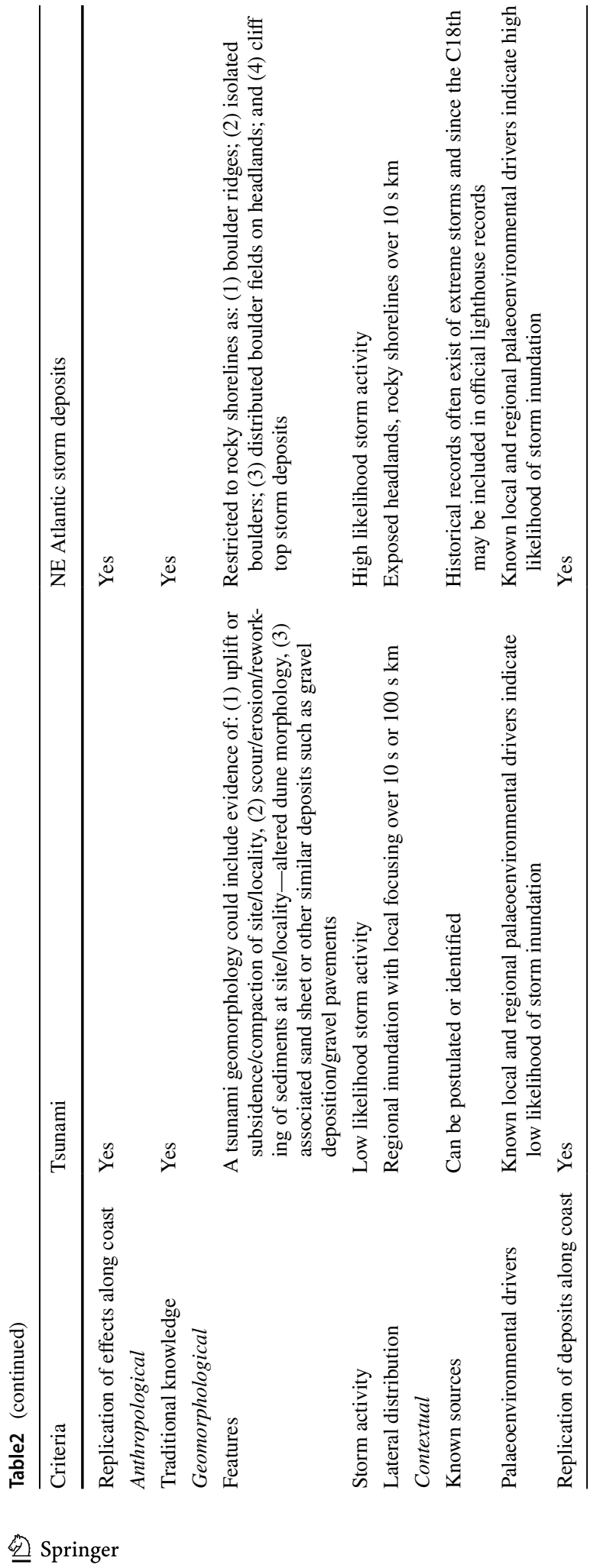


Deposits associated with major tsunamis extend much further inland and cover higher topography; however, the extent of the deposit cannot be used to distinguish less-extreme events from storm deposits. Biological debris can include continuous shell layers, perhaps nearer the top of the sequence in tsunami deposits. In storm deposits, shell material tends to occur only as interstitial material in the inland portion of the deposit. Archaeological sites can be buried by tsunamis but are eroded by storm wave action. Geomorphologically, tsunamis may be locally focused but inundate whole shorelines, whereas storm deposits are restricted, mainly, to exposed rocky headlands. Storm deposits are necessarily the result of multiple events with their geology being most affected by extreme events (e.g., Dewey and Ryan 2017). Exposed coasts may be subject to both storm and tsunami deposits. The greater transport power of tsunamis is likely to overwhelm the structure of earlier storm deposits, whilst later storm deposits may modify that portion of a tsunami adjacent to the shoreline.

\section{Similarities and differences}

It is evident that tsunamis and storms often have similar characteristics, be this in boulder mass, extent inland, fining inland, or geology. While the deposits may initially appear similar, there are invariably some differences either associated with the boulder deposits and/ or with the nature of the depositional environment and/or associated finer sediments if present. They key to differentiating between tsunami and storm deposits lies in a comprehensive analysis of all available data. Inevitably, there are rare instances where it is impossible to determine whether boulders were laid down by a storm or a tsunami. This is invariably due to insufficient data (e.g., Chatham Island: Goff et al. 2018), but in such cases it is worth noting that while differentiating between the two processes is impossible, the coastline in question has experienced a significant high energy marine inundation.

\section{Conclusions}

We have identified 14 mechanisms, five of which: tsunami; storms; waterspouts, cliff collapse; and catastrophic flooding below sea level, may produce deposits stretching for significant distances along shorelines. The latter three mechanisms should be identifiable through field or remote mapping. The distinction of boulder deposits resulting from tsunami(s) or storm(s), both of which may occur in the same location, is less clear. We argue that features such as size, mass, along shore extent and clast shape are not uniquely characteristic of either type of deposit. Rather, a wide variety of parameters, which reflect the period and the frequency of the transporting waves, need to be taken into account.

\section{Appendix 1}

Relationships between mass, intermediate axis length and shape factor.

The shape factor $(k)$ is defined as:

(i) $k=\frac{A / B}{B / C}$ 
where $A, B$ and $C$ represent the maximum, intermediate and minimum dimensions in meters respectively (Flinn 1962).

The mass $(\mathrm{m})$ of a rectangular cuboid clast in $\mathrm{kg}$ is given by:

$$
\text { (ii) } m=A B C \rho
$$

or for an ellipsoid

$$
\text { (iii) } \quad m=\pi / 6 A B C \rho
$$

where $m=\mathrm{kg} \mathrm{m}^{-3}$.

Rearranging we have:

$$
\text { (iv) } \quad B^{3}=\frac{m}{\rho k} \text { (cuboid) }
$$

or

$$
\text { (v) } \quad B^{3}=\frac{m}{\rho k} \pi / 6 \text { (ellipsoid) }
$$

For the Zingg plot (1935) where the abscissa is $C / B$ and the ordinate $B / A$ the minimum mass $\left(m_{\mathrm{m}}\right)$ for a boulder of a given shape $(B=0.25 \mathrm{~m})$ or megaclast $(B=4.1 \mathrm{~m})$ we can rearrange (ii) and (iii) as follows:

$$
\begin{gathered}
\text { (vi) } \quad m_{\mathrm{m}}=\frac{B}{(B / A)} B(C / B) B \rho \text { (cuboid) } \\
\text { (vii) } \quad m_{\mathrm{m}}=\frac{B}{(B / A)} B(C / B) B \rho \pi / 6 \text { (ellipsoid) }
\end{gathered}
$$

Figure 1 plots the minimum mass for cuboid boulders of different shape factors where $B=0.25 \mathrm{~m}$ and $\rho=2600 \mathrm{~kg} \mathrm{~m}^{-3}$.

\section{Appendix 2}

Equations relating mode of transport to flow velocity derived from boulder geometry and mass after Nandasena et al. (2011a, 2013).

Sliding mode of transport:

$$
U^{2} \geq \frac{2\left(\rho_{\mathrm{s}} / \rho_{\mathrm{w}}-1\right) g C[\mu \cos (\theta)+\sin (\theta)]}{C_{\mathrm{d}}(C / B)+\mu C_{1}}
$$

Rolling mode of transport:

$$
U^{2} \geq \frac{2\left(\rho_{\mathrm{s}} / \rho_{\mathrm{w}}-1\right) g C[\cos (\theta)+(C / B) \sin (\theta)]}{C_{\mathrm{d}}\left(C^{2} / B^{2}\right)+C_{1}}
$$

Lifting mode of transport: 


$$
U^{2} \geq \frac{2\left(\rho_{\mathrm{s}} / \rho_{\mathrm{w}}-1\right) g C \cos (\theta)}{C_{1}}
$$

where $B=$ intermediate axis length $(\mathrm{m}) ; C=$ shortest axis length $(\mathrm{m}) ; C_{\mathrm{d}}=$ coefficient of $\operatorname{drag}=2.0 ; C_{1}=$ Coefficient of lift $=0.178 ; \mathrm{g}=$ gravitational acceleration $=9.81 \mathrm{~m} \mathrm{~s}^{-2}$; $\mu=$ coefficient of static friction $=0.7 ; \rho_{\mathrm{s}}=$ density of boulder $=2600 \mathrm{~kg} \mathrm{~m}^{-3} ; \rho_{\mathrm{w}}=$ density of sea water $=1024 \mathrm{~kg} \mathrm{~m}^{-3} ; \Theta=$ angle of slope $=2^{\circ}$.

The above values were used in constructing Fig. 5. Note that the range of bed slope in both locations was from $1.0^{\circ}$ to $3.8^{\circ}$. However, as specific values were not attributed to each boulder, a value of $2^{\circ}$ was used throughout.

Authors' contribution JFD proposed this review and provided a first draft. The text was then expanded and written by all three authors. PDR prepared the diagrams.

Funding Open Access funding provided by the IReL Consortium.

Data availability The data sources for this review are provided in the Reference section and any formulae used are provided in the "Appendix."

\section{Declarations}

Conflict of interest The authors declare that they have no conflict of interest.

Open Access This article is licensed under a Creative Commons Attribution 4.0 International License, which permits use, sharing, adaptation, distribution and reproduction in any medium or format, as long as you give appropriate credit to the original author(s) and the source, provide a link to the Creative Commons licence, and indicate if changes were made. The images or other third party material in this article are included in the article's Creative Commons licence, unless indicated otherwise in a credit line to the material. If material is not included in the article's Creative Commons licence and your intended use is not permitted by statutory regulation or exceeds the permitted use, you will need to obtain permission directly from the copyright holder. To view a copy of this licence, visit http://creativecommons.org/licenses/by/4.0/.

\section{References}

Adcock T, Taylor P, Yan S, Ma Q, Janssen P (2011) Did the Draupner wave occur in a crossing sea? Philos Trans R Soc A 467:3004-3021

Archer AW (2013) World's highest tides: hypertidal coastal systems in North America, South America and Europe. Sediment Geol 284:1-25

Archer D, Fowler H (2018) Characterising flash flood response to intense rainfall and impacts using historical information and gauged data in Britain. J Flood Risk Manage 11:S121-S133

Atwater BF, Uri S, Buckley M, Halley RS, Jaffe BE, López-Venegas AM, Reinhardt EG, Tuttle MP, Watt S, Wei Y (2012) Geomorphic and stratigraphic evidence for an unusual tsunami or storm a few centuries ago at Anegada, British Virgin Islands. Nat Hazards 63:51-84

Barbano M, Pirrotta C, Gerardi F (2010) Large boulders along the south-eastern Ionian coast of Sicily: storm or tsunami deposits? Mar Geol 275:140-154

Beaty CB (1989) Great big boulders I have known. Geology 17:349-352

Blott SJ, Pye K (2008) Particle shape: a review and new methods of characterization and classification. Sedimentology 55:31-63

Boulton SJ, Whitworth MR (2018) Block and boulder accumulations on the southern coast of Crete (Greece): evidence for the 365 CE tsunami in the Eastern Mediterranean. Geol Soc Lond Spec Pub 456:105-125

Bretz JH (1925) The Spokane flood beyond the channelled scablands. J Geol 33:97-115

Bryant E, Nott J (2001) Geological indicators of large tsunami in Australia. Nat Hazards 24:231-249 
Bryant EA, Young R (1996) Bedrock-sculpturing by tsunami, south coast New South Wales, Australia. J Geol 104:565-582

Burke K, Sengör AC (1988) Ten metre global sea-level change associated with South Atlantic Aptian salt deposition. Mar Geol 83:309-312

Cain G, Goff J, McFadgen B (2019) Prehistoric coastal mass burials: did death come in waves? J Archaeol Method Theory 26:714-754

Chanson H (2012) Tidal bores, aegir, eagre, mascaret, pororoca: Theory and observations. World Scientific, Singapore

Cheng D, Cui Y, Su F, Jia Y, Choi CE (2018) The characteristics of the Mocoa compound disaster event, Colombia. Landslides 15:1223-1232

Chigira M, Wang W-N, Furuya T, Kamai T (2003) Geological causes and geomorphological precursors of the Tsaoling landslide triggered by the 1999 Chi-Chi earthquake. Taiwan Eng Geol 68:259-273

Conway W (1900) The Alps from end to end. Westminster Press, Philadelphia

Costa JE (1983) Paleohydraulic reconstruction of flash-flood peaks from boulder deposits in the Colorado Front Range. Geol Soc Am Bull 94:986-1004

Courtney C, Dominey-Howes D, Goff J, Chagué-Goff C, Switzer AD, McFadgen B (2012) A synthesis and review of the geological evidence for palaeotsunamis along the coast of southeast Australia: the evidence, issues and potential ways forward. Quaternary Sci Rev 54:99-125

Cox R (2020) Megagravel deposits on the west coast of Ireland show the impacts of severe storms. Weather 75:72-77

Cox R, Zentner DB, Kirchner BJ, Cook MS (2012) Boulder ridges on the Aran Islands (Ireland): Recent movements caused by storm waves, not tsunamis. J Geol 120:249-272

Cox R, Jahn KL, Watkins OG, Cox P (2018) Extraordinary boulder transport by storm waves (west of Ireland, winter 2013-2014), and criteria for analysing coastal boulder deposits. Earth-Sci Rev 177:623-636

Cox R, Ardhuin F, Dias F, Autret R, Beisiegel N, Earlie CS, Herterich JG, Kennedy A, Paris R, Raby A (2020) Systematic review shows that work done by storm waves can be misinterpreted as tsunamirelated because commonly used hydrodynamic equations are flawed. Front Mar Sci 7:4. https://doi.org/ 10.3389/fmars.2020.00004

Cunha PP, Gouveia MP (2015) The Nazaré coast, the submarine canyon and the giant waves: a synthesis. Faculty of Sciences and Technology Department of Earth Sciences, vol 30

Dawson A, Stewart I (2008) Tsunami deposits in the geological record. Sediment Geol 211:92-93

DeBlasio FV, Elverhøi A (2008) A model for frictional melt production beneath large rock avalanches. J Geophys Res. https://doi.org/10.1029/2007JF000867

Dewey JF, Ryan PD (2017) Storm, rogue wave, or tsunami origin for megaclast deposits in western Ireland and North Island, New Zealand? Proc Natl Acad Sci USA 114:E10639-E10647

Eireann M (2019). https://www.met.ie/climate/available-data/historical-data (Belmullet). https://www.met. ie//climate/available-data/historical-data. Accessed 2 May 2019

Evenson EB, Burkhart PA, Gosse JC, Baker GS, Jackofsky D, Meglioli A, Dalziel I, Kraus S, Alley RB, Berti C (2009) Enigmatic boulder trains, supraglacial rock avalanches, and the origin of "Darwin's boulders", Tierra del Fuego. GSA Today 19:4-10

Flinn D (1962) On folding during three-dimensional progressive deformation. Q J Geol Soc Lond 118:385-428

Fritz HM, Mohammed F, Yoo J (2009) Lituya bay landslide impact generated mega-tsunami 50th anniversary. Pure Appl Geophys 166:153-175

Frohlich C, Hornbach MJ, Taylor FW, Shen C-c, Moala A, Morton AE, Kruger J (2009) Huge erratic boulders in Tonga deposited by a prehistoric tsunami. Geology 37:131-134

Garcia-Castellanos D, Estrada F, Jiménez-Munt I, Gorini C, Fernández M, Vergés J, De Vicente R (2009) Catastrophic flood of the Mediterranean after the Messinian salinity crisis. Nature 462:778-781

Goff J, Hulme K, McFadgen B (2003) "Mystic Fires of Tamaatea": attempts to creatively rewrite New Zealand's cultural and tectonic past. J R Soc New Zeal 33:795-809

Goff J, Dudley W, deMaintenon M, Cain G, k, Coney J, (2006) The largest local tsunami in 20th century Hawaii. Mar Geol 226:65-79

Goff J, Weiss R, Courtney C, Dominey-Howes D (2010) Testing the hypothesis for tsunami boulder deposition from suspension. Mar Geol 277:73-77

Goff J, Chagué-Goff C, Nichol S, Jaffe B, Dominey-Howes D (2012) Progress palaeotsunami research. Sediment Geol 243:70-88

Goff J, McFadgen B, Chagué-Goff C, Goto K, Nichol S (2016) Putting a spin on palaeotsunami deposits. Earth Surf Process 41:1293-1296 
Goff J, Goto K, Chagué C, Watanabe M, Gadd P, King D (2018) New Zealand's most easterly palaeotsunami deposit confirms evidence for major trans-Pacific event. Mar Geol 404:158-173

Goto K, Miyagi K, Kawamata H, Imamura F (2010) Discrimination of boulders deposited by tsunamis and storm waves at Ishigaki Island, Japan. Mar Geol 269:34-45

Hall AM (2011) Storm wave currents, boulder movement and shore platform development: a case study from East Lothian, Scotland. Mar Geol 283:98-105

Hall AM, Hansom JD, Williams DM, Jarvis J (2006) Distribution, geomorphology and lithofacies of clifftop storm deposits: Examples from the high-energy coasts of Scotland and Ireland. Mar Geol 232:131155. https://doi.org/10.1016/j.margeo.2006.06.008

Hung J-J (2000) Chi-Chi earthquake induced landslides in Taiwan. Earthq Eng Seismol 2:25-33

Hung J-J, Lee C-T, Lin M-L (2002) Tsao-ling rockslides, Taiwan. Geol Soc Am Rev Eng Geol 15:91-115

Iadanza C, Trigila A, Vittori E, Serva L (2009) Landslides in coastal areas of Italy. Geol Soc Lond Spec Pub 322:121-141

Ichinose GA, Anderson JG, Satake K, Schweickert RA, Lahren MM (2000) The potential hazard from tsunami and seiche waves generated by large earthquakes within Lake Tahoe, California-Nevada. Geophys Res Lett 27:1203-1206

Kilburn CR, Petley DN (2003) Forecasting giant, catastrophic slope collapse: lessons from Vajont, Northern Italy. Geomorphology 54:21-32

Liao H-W (2000) Landslides triggered by Chi-Chi earthquake. (Master's Thesis). Institute of Geophysics, National Central University (in Chinese).

Lorenz RD, Jackson BK, Barnes JW, Spitale J, Keller JM (2011) Ice rafts not sails: floating the rocks at Racetrack Playa. Am J Phys 79:37-42

Mattioli G, Voight B, Linde A, Sacks I, Watts P, Widiwijayanti C, Young S, Hidayat D, Elsworth D, Malin P (2007) Unique and remarkable dilatometer measurements of pyroclastic flow-generated tsunamis. Geology 35:25-28

McConnell RG, Brock RW (1904) Report on the great landslide at Frank, Alberta. Canada Department interior annual report, pp 1-17

McFadgen B, Goff J (2007) Tsunamis in the New Zealand archaeological record. Sediment Geol 200:263-274

McGreal W (1979) Marine erosion of glacial sediments from a low-energy cliffline environment near Kilkeel, Northern Ireland. Mar Geol 32:89-103

McMurtry GM, Fryer GJ, Tappin DR, Wilkinson IP, Williams M, Fietzke J, Garbe-Schoenberg D, Watts P (2004) Megatsunami deposits on Kohala volcano, Hawaii, from flank collapse of Mauna Loa. Geology 32:741-744

Melosh HJ (1987) The mechanics of large rock avalanches. Rev Eng Geol 7:41-50

Micallef A, Camerlenghi A, Garcia-Castellanos D, Otero DC, Gutscher M-A, Barreca G, Spatola D, Facchin L, Geletti R, Krastel S (2018) Evidence of the Zanclean megaflood in the eastern Mediterranean Basin. Sci Rep 8:1078

Miller DJ (1960) Giant waves in Lituya bay, Alaska. In: Alaska. geological survey professional paper 354-C. U. S. Government Printing Office, Washington, pp 253-266

Montoya L, Lynett P (2018) Tsunami versus infragravity surge: comparison of the physical character of extreme runup. Geophys Res Lett 45:12-982

Moore JG, Schweickert RA, Robinson JE, Lahren MM, Kitts CA (2006) Tsunami-generated boulder ridges in Lake Tahoe, California-Nevada. Geology 34:965-968

Nandasena N, Paris R, Tanaka N (2011a) Numerical assessment of boulder transport by the 2004 Indian ocean tsunami in Lhok Nga, West Banda Aceh (Sumatra, Indonesia). Comput Geosci 37:1391-1399

Nandasena NAK, Paris R, Tanaka N (2011b) Reassessment of hydrodynamic equations: Minimum flow velocity to initiate boulder transport by high energy events (storms, tsunamis). Mar Geol 281:7084. https://doi.org/10.1016/j.margeo.2011.02.005

Nandasena N, Tanaka N, Sasaki Y, Osada M (2013) Boulder transport by the 2011 Great East Japan tsunami: Comprehensive field observations and whither model predictions? Mar Geol 346:292-309

Noormets R, Crook KA, Felton EA (2004) Sedimentology of rocky shorelines: 3. Hydrodynamics of megaclast emplacement and transport on a shore platform, Oahu, Hawaii. Sediment Geol 172:41-65

Nott J (2003) Waves, coastal boulder deposits and the importance of the pre-transport setting. Earth Planet Sci Lett 210:269-276. https://doi.org/10.1016/S0012-821X(03)00104-3

Nott J, Green C, Townsend I, Callaghan J (2014) The world record storm surge and the most intense Southern Hemisphere tropical cyclone: new evidence and modeling. B Am Meteorol Soc 95:757-765 
O’Brien L, Dudley JM, Dias F (2013) Extreme wave events in Ireland: 14680 BP-2012. Nat Hazards Earth Syst Sci 13:625

Plafker G, Ericksen GE, Concha JF (1971) Geological aspects of the May 31, 1970, Peru earthquake. B Seismol Soc Am 61:543-578

Ramalho RS, Winckler G, Madeira J, Helffrich GR, Hipólito A, Quartau R, Adena K, Schaefer JM (2015) Hazard potential of volcanic flank collapses raised by new megatsunami evidence. Sci Adv 1:e1500456

Rana N, Singh S, Sundriyal Y, Juyal N (2013) Recent and past floods in the Alaknanda valley: causes and consequences. Curr Sci 105:1209-1212

Richmond BM, Watt S, Buckley M, Jaffe BE, Gelfenbaum G, Morton RA (2011) Recent storm and tsunami coarse-clast deposit characteristics, southeast Hawaii. Mar Geol 283:79-89

Scheffers A, Kelletat D (2003) Sedimentologic and geomorphologic tsunami imprints worldwide-a review. Earth Sci Rev 63:83-92

Simkin T, Fiske R (1983) Krakatau, 1883: the volcanic eruption and its effects. Smithsonian Institution Press, Washington DC

Smit J, Roep TB, Alvarez W, Montanari A, Claeys P, Grajales-Nishimura JM, Bermudez J (1996) Coarse-grained, clastic sandstone complex at the K/T boundary around the Gulf of Mexico: Deposition by tsunami waves induced by the Chicxulub impact? Geol Soc Am Spec Pap 307:151-182

Spiske M, Garcia Garcia A-M, Tsukamoto S, Schmidt V (2020) High-energy inundation events versus longterm coastal processes - room for misinterpretation. Sedimentology 67:1460-1480. https://doi.org/10. $1111 /$ sed.12524

Stark TD, Baghdady AK, Hungr O, Aaron J (2017) Case study: Oso, Washington, landslide of March 22, 2014 - material properties and failure mechanism. J Geotech Geoenviron 143:05017001

Suanez S, Fichaut B, Magne R (2009) Cliff-top storm deposits on Banneg Island, Brittany, France: effects of giant waves in the Eastern Atlantic Ocean. Sediment Geol 220:12-28

Sunamura T (1985) A simple relationship for predicting wave height in the surf zone with a uniformly sloping bottom. Trans Jpn Geomorph Union 6:361-364

Terry JP, Goff J (2014) Megaclasts: proposed revised nomenclature at the coarse end of the udden-wentworth grain-size scale for sedimentary particles. J Sediment Res 84:192-197. https://doi.org/10.2110/ jsr.2014.19

Terry JP, Goff J, Jankaew K (2018) Major typhoon phases in the upper Gulf of Thailand over the last 1.5 millennia, determined from coastal deposits on rock islands. Quatern Int 487:87-98

Thomas D, Schmidt P (2018) Paleomagnetic evidence for the emplacement mechanism of an enigmatic boulder accumulation on a coastal cliff top in New South Wales: implications for the Australian Megatsunami Hypothesis. Aust J Earth Sci 65:503-515

Tyler P, Amaro T, Arzola R, Cunha MR, De Stigter H, Gooday A, Huvenne V, Ingels J, Kiriakoulakis K, Lastras G (2009) Europe's grand canyon Nazaré submarine canyon. Oceanography 22:46-57

Violante C (2009) Rocky coast: geological constraints for hazard assessment. Geol Soc Lond Spec Pub $322: 1-31$

Waltham T (2018) St Francis: the world's worst dam site. Geol Today 34:100-108

Wang DW, Mitchell DA, Teague WJ, Jarosz E, Hulbert MS (2005) Extreme waves under hurricane Ivan. Science 309:896-896

Watanabe M, Goto K, Imamura F, Kennedy A, Sugawara D, Nakamura N, Tonosaki T (2019) Modeling boulder transport by coastal waves on cliff topography: case study at Hachijo Island, Japan. Earth Surf Process 44:2939-2956

White AB, Moore BJ, Gottas DJ, Neiman PJ (2019) Winter storm conditions leading to excessive runoff above California's Oroville Dam during January and February 2017. B Am Meteorol Soc 100:55-70

Williams DM, Hall AM (2004) Cliff-top megaclast deposits of Ireland, a record of extreme waves in the North Atlantic-storms or tsunamis? Mar Geol 206:101-117

Zingg T (1935) Beitrag Zur Schotteranalyse. Schweiz Miner Petrog 15:39-140

Publisher's Note Springer Nature remains neutral with regard to jurisdictional claims in published maps and institutional affiliations. 